\title{
PELATIHAN PEMANFAATAN KAIN PERCA SEBAGAI APE PILLOW DOLL UNTUK PEMBELAJARAN ANAK USIA DINI DI KUWASEN JEPARA
}

\author{
Aliva Rosdiana, Hayu Dian Yulistianti, Azzah Nor Laila \\ Universitas Islam Nahdlatul Ulama Jepara \\ email: alivarosdiana1983@gmail.com
}

Key word:

Rags, Educational Props, Pillow Doll, creativity.

\author{
Kata Kunci \\ Kain Perca, APE, \\ Pillow Doll, \\ kreatifitas
}

\begin{abstract}
This community service aims to provide supplies for the partners, namely Ibu PKK RT 16 RW 5 of Kuwasen Village Jepara, in the form of materials and training of educative props to improve creativity of PKK mothers in the village of Kuwasen, Jepara Sub-district, Jepara Regency, Java Central. The implementation methods include socialization of waste processing waste and creativity motivation makemaking educational tool for home education. Furthermore, the devotees team provides training on making pillow doll from the patchwork of fruit (fruit or buahaz) and hijaiyah. Method of implementation of community service that has been implemented consists of three stages. The first stage is socialization and counseling of waste management waste and preparation of APE making. The second stage is the assistance and training of APE making. And the last is the evaluation stage. Our hope after the implementation of this devotion is the increase of creativity by PKK mothers in accordance with the capacity building that has become an integral part of the world of home education, children, and science that continues to grow.
\end{abstract}
Abstrak
Pengabdian ini bertujuan untuk memberikan bekal bagi para mitra yaitu Ibu-Ibu PKK RT 16 RW 5 Desa Kuwasen Jepara, berupa materi dan pelatihan pembuatan alat peraga edukatif untuk meningkatkan kreatifitas para Ibu-ibu PKK di desa Kuwasen, Kecamatan Jepara, Kabupaten Jepara, Jawa Tengah. Metode pelaksanaannya meliputi sosialisasi mengenai pengolahan limbah sampah dan pemberian motivasi kreativitas pembuatan alat peraga edukatif untuk pembelajaran dalam rumah (home education). Selanjutnya tim pengabdi memberikan pelatihan pembuatan pillow doll dari kain perca bertemakan buah-buahan (fruit) dan huruf hijaiyah. Metode pelaksanaan pengabdian masyarakat yang telah dilaksanakan terdiri atas tiga tahap. Tahap pertama yaitu sosialisasi dan penyuluhan pengelolaan limbah sampah dan persiapan pembuatan APE. Tahap ke-dua yaitu pendampingan dan pelatihan pembuatan APE. Dan yang terakhir yaitu tahap evaluasi. Harapan kami setelah pelaksanaan pengabdian ini adalah terjadinya peningkatan kreatifitas oleh ibu-ibu PKK sesuai dengan capacity building yang dimilikinya sehingga menjadi bagian yang tak terpisahkan antara dunia home education, anak, serta ilmu pengetahuan yang terus berkembang. 


\section{PENDAHULUAN}

Keresahan masyarakat terhadap lingkungan yang tidak pernah ada habisnya adalah masalah sampah. Dampak penumpukan sampah sangat beragam, diantaranya banjir, pemanasan global, dan pencemaran lingkungan. Pengolahan dan pengadaan bank sampah menjadi salah satu cara menyadarkan masyarakat untuk mengumpulkan serta memilah sampah sesuai dengan jenisnya baik organik maupun anorganik. Selain itu perlu didukung dengan kegiatan penyuluhan mengenai 3R yaitu reduce (mengurangi), reuse (menggunakan kembali), dan recycle (mendaur ulang).

Sampah atau barang bekas yang terdapat di rumah sangat variatif. Mulai kardus, botol, plastik, dan kain perca. Kain perca adalah potongan kain-kain kecil sisa dari bahan baju baik dari penjahit, maupun potongan baju yang sudah tidak terpakai. Selama ini kain perca hanya ditumpuk dan kurang banyak dimanfaatkan. Hal itu juga terjadi di desa Kuwasen yang mayoritas masyarakatnya ibu-ibu rumahan.

Kuwasen adalah salah satu desa di kecamatan Jepara. Desa Kuwasen menurut penggunaannya memiliki luas sekitar 32.417, 91 Ha meliputi persawahan, kuburan, pekarangan, perkantoran, dan prasarana umum lainnya. Jumlah populasi penduduk sebanyak 4556 orang meliputi jumlah laki-laki 2425 orang, perempuan 2131 orang, dan total kepala keluarga sebanyak 1130. Desa ini terletak diantara desa Bandengan yang merupakan salah satu desa pesisir pantai, dan desa Mulyoharjo yang dikenal sebagai sentra produksi patung.

Desa Kuwasen memiliki penduduk heterogen, mulai pegawai, pengusaha, dan ibu rumah tangga. Kawasan di desa ini juga terbagi menjadi beberapa komplek, diantaranya komplek perumahan Kuwasharjo. Komplek Perum Kuwasharjo ini merupakan kelompok masyarakat yang mayoritas pendatang dari luar Jepara. Sehingga secara personal, warga membutuhkan banyak adaptasi. Baik dalam hal interaksi sosial antar warga, juga persoalan lingkungan. Keluhan dan masalah yang dianggap penting oleh warga perum Kuwasharjo Kuwasen ini adalah kurangnya kesadaran pengolahan sampah.

Ide dan realisasi membuat bank sampah pernah berjalan hanya beberapa waktu dikumpulkan di dua rumah warga. Namun setelah itu tidak ada lagi tindak lanjut karena enggan, sungkan, dan khawatir sampah-sampah yang dikirim ke rumah warga tersebut mencemari lingkungan tempat tinggal warga petugas bank sampah. Di sisi lain, Warga masih beranggapan sampah sebagai barang sisa yang tidak berguna. 
Paradigma warga tentang tidak adanya manfaat barang bekas atau sampah tersebut perlu dirubah. Perlu dikenalkan bahwa sampah juga dapat memiliki nilai ekonomis yang bisa dimanfaatkan. Untuk itu perlu adanya motivasi kesadaran kepada warga pentingnya menjaga lingkungan salah satunya dengan mengurangi produksi sampah dengan recycle (daur ulang) menjadi sesuatu yang bermanfaat, diantaranya menjadi Alat Peraga Edukatif (APE) sebagai media home education.

\section{METODE PELAKSANAAN}

Metode pelaksanaan pengabdian masyarakat pemanfaatan sampah kain perca ini adalah 1). Kunjungan Lapangan, survei ke lokasi mitra dilaksanakan sebelum pelaksanaan untuk mengetahui permasalahan mitra dan mengkomunikasikan tawaran solusi pada mitra. 2). Ceramah, metode ini digunakan saat memberikan motivasi dan penyuluhan. 3). Praktek, peserta mengikuti pelatihan dan praktek pembuatan APE dari kain perca dan tim pengabdi melakukan pendampingan 4). Diskusi, metode ini digunakan baik saat penyampaian motivasi, workshop, dan evaluasi kegiatan bersama mitra. Tahapan pengabdian masyarakat ini meliputi persiapan, pelaksanaan, dan evaluasi sebagaimana pada gambar 1.

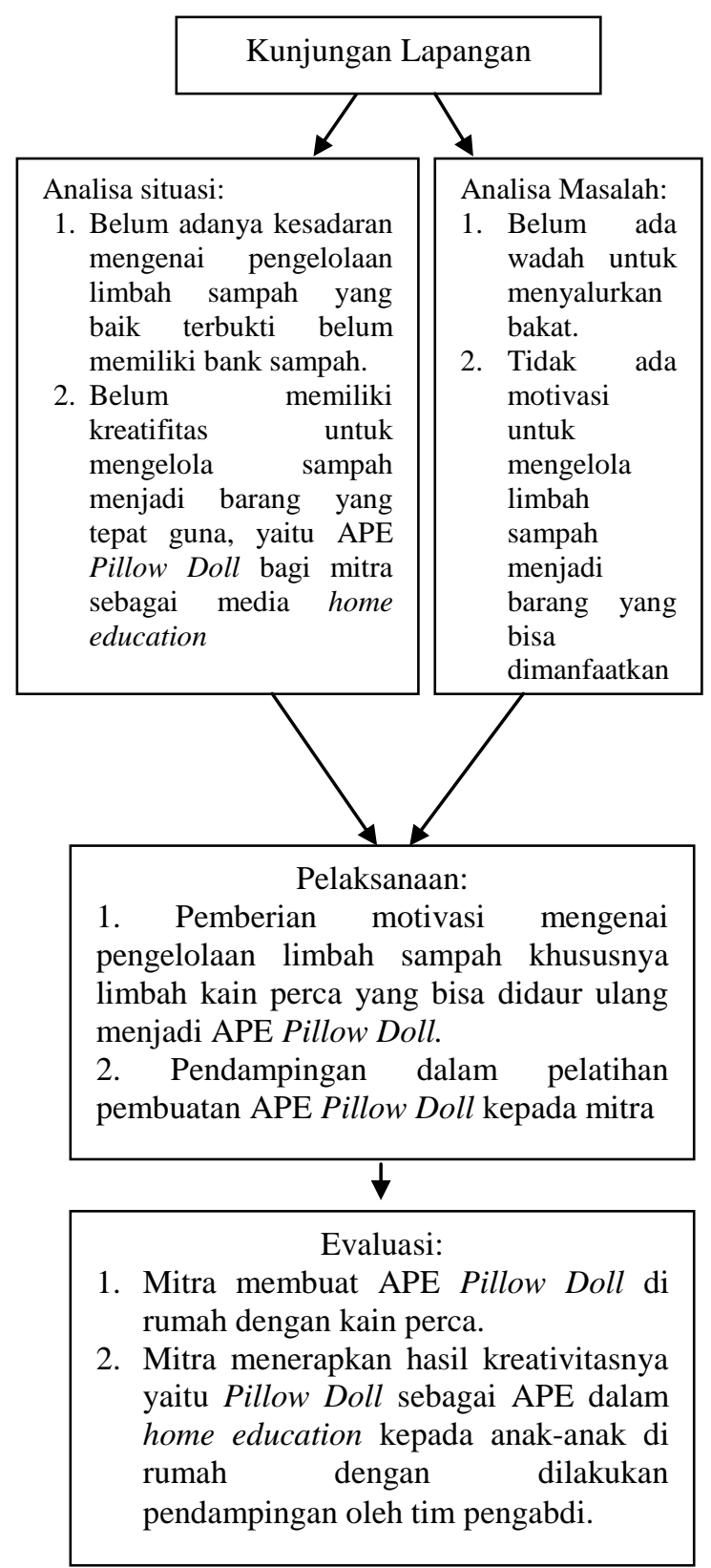

Gambar 1. Tahapan Pengabdian Masyarakat 


\section{PEMBAHASAN}

Kegiatan pengabdian masyarakat ini fokus pada pemanfaatan limbah kain perca sebagai APE. Mitra tim pengabdian ini adalah ibu-ibu PKK perumahan Kuwasharjo di desa Kuwasen Rt. 16 Rw. 5 Jepara. Dalam pelaksanaan kegiatan, tim pengabdi mengundang narasumber aktivis parenting sekaligus wakil PKK serta tim pengabdi sebagai tutor. Materi yang diberikan oleh narasumber meliputi motivasi kesadaran akan sampah dan pengelolaannya, peningkatan kreatifitas pengelolaan sampah, dan kreatifitas pembuatan APE Pillow Doll. Hasil yang diperoleh dari kegiatan pengabdian masyarakat sebagai berikut:

\section{a. Menumbuhkan}

Kesadaran

\section{Mengelola Sampah}

Kelompok ibu-ibu PKK Perum Kuwasharjo desa Kuwasen diberi motivasi dan penyuluhan tentang pengelolaan limbah sampah. Diantaranya memotivasi peserta agar menyadari pentingnya mengelola sampah, serta mengolahnya menjadi sesuatu yang bermanfaat. Sampah di lingkungan tidak semuanya bisa hancur dan menyatu dengan alam. Maka diperlukan kesadaran warga masyarakat untuk mendaur ulang sampah yang tidak terpakai. Salah satunya adalah kain perca yang mudah didapatkan. Hal itu didukung dengan kegemaran serta keahlian ibu-ibu dalam menjahit, sehingga limbah kain perca dapat dimanfaatkan menjadi boneka bantal (pillow doll).

Kain perca diperoleh dari sisa kain yang biasanya oleh penjahit dalam industry konveksi kumpulkan dan seringkali dibuang atau diberikan bagi yang menginginkannya. Kami tim pengabdi memanfaatkan kain perca tersebut dalam pembuatan APE sesuai dengan bidang keilmuan tim dalam bidang pendidikan. Penerapan APE Pillow Doll ini terinspirasi dari artikel berjudul "Capasity Building Guru Ra Asy-Syafi'iyyah Pekalongan Jepara Melalui Edukasi APE Softbook (Buku Bantal) Berbahasa Inggris Dari Spons Ati." Santi $d k k$ memanfaatkan spons ati dalam pembuatan APE softbook sebagai bahan ajar oleh guru-guru RA AsySyafi'iyyah di Pekalongan Jepara.

Tahap awal kegiatan pengabdian ini dilakuan sosialisasi dan motivasi kepada mitra akan pentingnya pemanfaatan limbah sampah untuk diterapkan dalam penggunaan APE bagi anak-anak usia dini. 


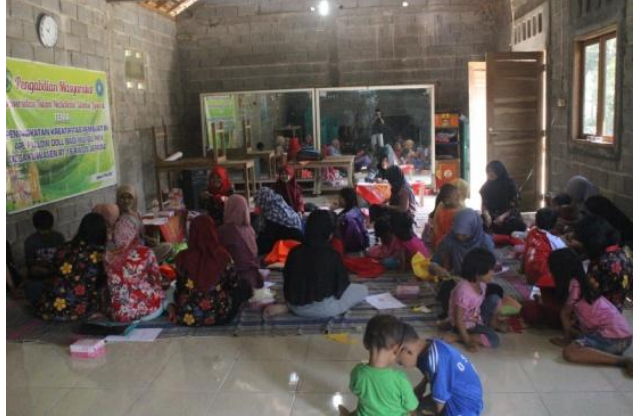

Gambar 2. Pendampingan dalam memberikan Motivasi serta Penyuluhan

\section{b. Pembuatan APE dari Kain Perca}

Pelaksanaan kegiatan selanjutnya yaitu workshop pembuatan alat peraga edukatif (APE) oleh tim pengabdi. Dalam kegiatan workshop ini peserta berkumpul secara kolosal mengikuti penyampaian materi dari tim tentang pentingnya APE dalam pembelajaran anak usia dini di rumah. Kemudian dijelaskan bahan-bahan untuk membuat APE Pillow Doll.

Selanjutnya peserta dibagi menjadi tiga kelompok kecil yang didampingi tim pengabdi sebagai tutor. Masingmasing kelompok diajari secara langsung tahap pemilihan bentuk yang diinginkan, pembuatan pola dasar dengan menggambar di kertas, menggunting bahan mengikuti pola, proses menjahit, mengisi pola dengan kain perca, proses merapikan, sehingga menjadi Pillow Doll. Tahap-tahap pelatihan pembuatan APE Pillow Doll sebagaimana pada gambar 3, 4, dan 5 .

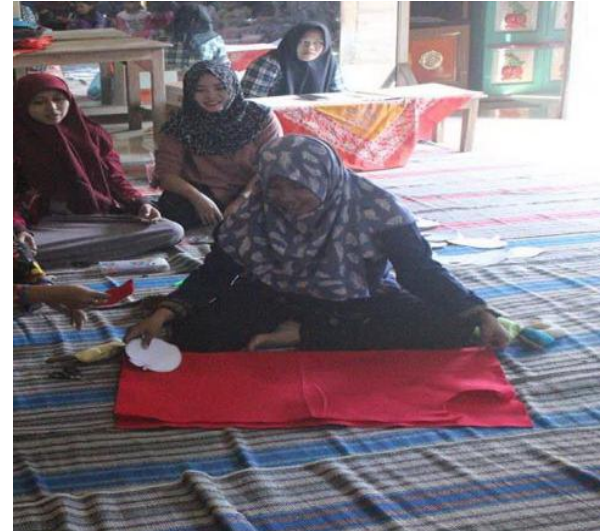

Gambar 3 : Pelatihan cara membuat pola

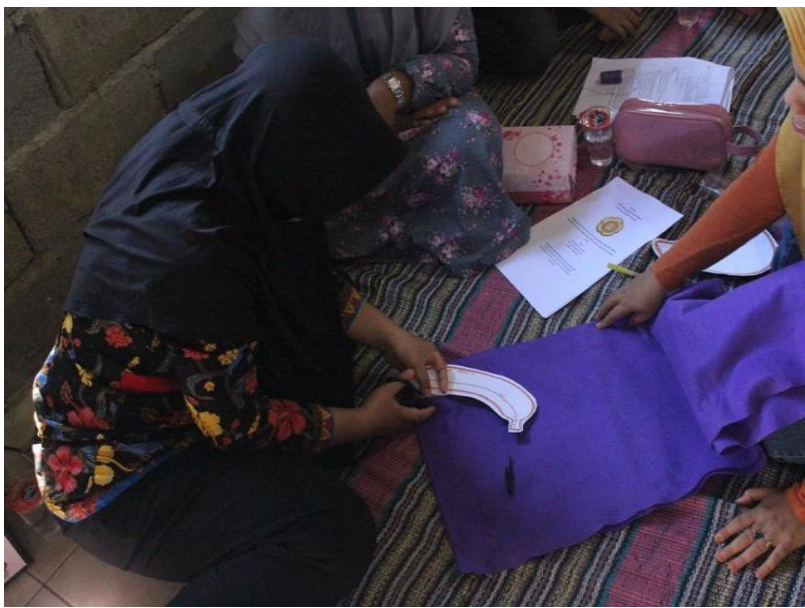

Gambar 4: Proses menggunting pola

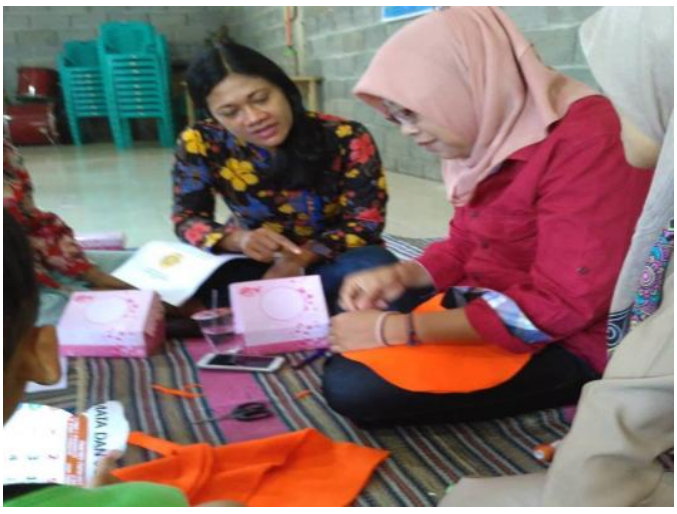

Gambar 6: Proses menjahit 


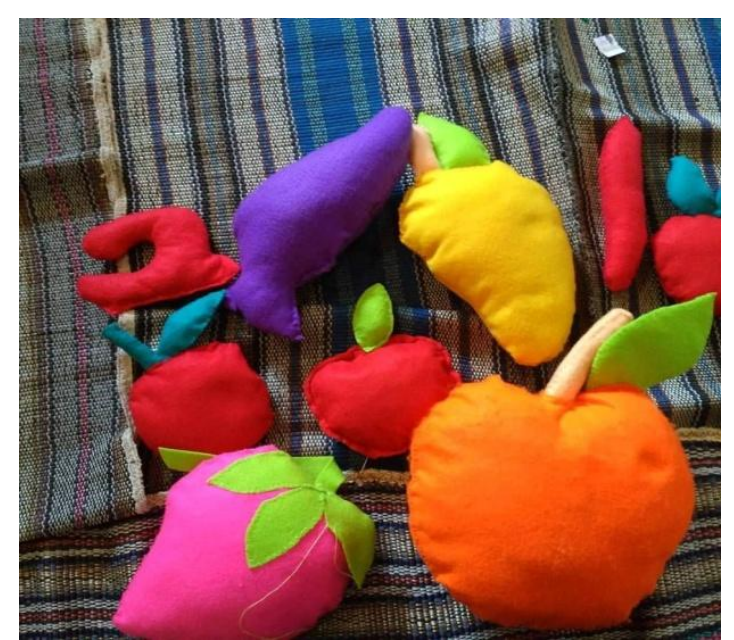

Gambar 7 : Hasil Jadi APE Pillow Doll

\section{KESIMPULAN}

Kegiatan Pengabdian Masyarakat yang dilaksanakan tim Pengabdi memilih lokasi desa Kuwasen dimana ketika tim pengabdi melakukan kunjungan lapangan ditemukan bahwa desa tersebut belum memiliki bank sampah. Dibuktikan pula dari hasil wawancara dengan ketua PKK bahwa sebelumnya pernah digagas mengenai bank sampah namun hanya jalan sebentar saja dikarenakan kurangya minat dan antusias warga serta tidak ada yang bisa mengelola limbah sampah untuk menjadi kreativitas yang bernilai tinggi.

Setelah ditemukan permasalahan, tim pengabdi bertindak untuk mencari solusi dengan peningkatan kreativitas ibuibu PKK sebagai mitra dalam pembuatan boneka bantal (pillow doll) sebagai media pembelajaran. Adapun tahap pelaksanaannya ada dua, yaitu yang pertama, penyuluhan mengenai pengelolaan sampah dan motivasi kreativitas pengelolaan limbah sampah menjadi barang bernilai tinggi dan memiliki nilai manfaat. Yang kedua, tutorial pembuatan boneka bantal dari limbah kain perca menjadi sesuatu yang bernilai dan bermanfaat sebagai alat peraga edukatif bagi ibu-ibu di rumah (home education). Pada akhirnya tim pengabdi melakukan evaluasi kunjungan memastikan bahwa hasil dari pelaksanaan kegiatan diterapkan di rumah sebagai media pembelajaran bagi anak-anak usia dini.

\section{SARAN}

Pelaksanaan pengabdian masyarakat oleh tim pengabdi diharapkan dilaksanakan pula di desa-desa khususnya yang ada di Jepara. Karena pada dasarnya tiap kreatifitas dimiliki masing-masing individu dengan skill yang berbeda. Pengelolaan limbah tidak hanya mengelola kain perca saja, namun limbah lain seperti plastik juga bisa didaur ulang menjadi barang bernilai tinggi. Harapan dari pengabdian ini adalah hasil yang berkesinambungan oleh tim pengabdi kepada mitra dalam pembuatan boneka bantal dari kain perca dan penerapannya dalam home education.

\section{UCAPAN TERIMA KASIH}

Terima kasih kepada LPPM UNISNU Jepara melalui program 
pengabdian regular monotahun atas

kepercayaan dan dana yang telah

diberikan.

\section{DAFTAR PUSTAKA}

Andriyani, S., Rosdiana, A., \& Ariyanto, A. (2017). CAPASITY BUILDING GURU RA ASY-SYAFI'IYYAH PEKALONGAN JEPARA MELALUI EDUKASI APE SOFTBOOK (BUKU BANTAL) BERBAHASA INGGRIS DARI SPONS ATI. J-ABDIPAMAS (Jurnal Pengabdian Kepada Masyarakat), 1(1), 24-30.

Suharsimi, Arikunto. "Manajemen penelitian." Jakarta: $\quad$ Rineka Cipta (2005).

Ditsardik Depdikbud. http://staff.uny.ac.id/sites/default/file s/lain-lain/sisca-rahmadonna-spdmpd/ALAT\%20PERAGA.pdf, $\quad 21$ Februari 2017

Zaman, Badru. (2006). Pengembangan Alat Permainan Edukatif Untuk Taman Kanak-kanak. Diunduh dari http://file.upi.edu/Direktori/FIP/JUR. PGTK/197408062001121BADRU_ZAMAN/pengembangan APE_di_TK.pdf tanggal 3 Februari $\underline{2017 .}$.

Endang, M. (2013). Metode Penelitian Terapan Bidang Pendidikan. Bandung: Alfabeta. 